\title{
CFD Models of a Serpentine Inlet, Fan, and Nozzle
}

R.V. Chima, D.J. Arend, R.S. Castner, and J.W. Slater

Glenn Research Center, Cleveland, Ohio

P.P. Truax

Lockheed Martin Corporation, Fort Worth, Texas 


\section{NASA STI Program . . . in Profile}

Since its founding, NASA has been dedicated to the advancement of aeronautics and space science. The NASA Scientific and Technical Information (STI) program plays a key part in helping NASA maintain this important role.

The NASA STI Program operates under the auspices of the Agency Chief Information Officer. It collects, organizes, provides for archiving, and disseminates NASA's STI. The NASA STI program provides access to the NASA Aeronautics and Space Database and its public interface, the NASA Technical Reports Server, thus providing one of the largest collections of aeronautical and space science STI in the world. Results are published in both non-NASA channels and by NASA in the NASA STI Report Series, which includes the following report types:

- TECHNICAL PUBLICATION. Reports of completed research or a major significant phase of research that present the results of NASA programs and include extensive data or theoretical analysis. Includes compilations of significant scientific and technical data and information deemed to be of continuing reference value. NASA counterpart of peer-reviewed formal professional papers but has less stringent limitations on manuscript length and extent of graphic presentations.

- TECHNICAL MEMORANDUM. Scientific and technical findings that are preliminary or of specialized interest, e.g., quick release reports, working papers, and bibliographies that contain minimal annotation. Does not contain extensive analysis.

- CONTRACTOR REPORT. Scientific and technical findings by NASA-sponsored contractors and grantees.
- CONFERENCE PUBLICATION. Collected papers from scientific and technical conferences, symposia, seminars, or other meetings sponsored or cosponsored by NASA.

- SPECIAL PUBLICATION. Scientific, technical, or historical information from NASA programs, projects, and missions, often concerned with subjects having substantial public interest.

- TECHNICAL TRANSLATION. Englishlanguage translations of foreign scientific and technical material pertinent to NASA's mission.

Specialized services also include creating custom thesauri, building customized databases, organizing and publishing research results.

For more information about the NASA STI program, see the following:

- Access the NASA STI program home page at http://www.sti.nasa.gov

- E-mail your question via the Internet to help@ sti.nasa.gov

- Fax your question to the NASA STI Help Desk at 443-757-5803

- Telephone the NASA STI Help Desk at 443-757-5802

- Write to: NASA Center for AeroSpace Information (CASI) 7115 Standard Drive Hanover, MD 21076-1320 
NASA/TM-2010-216349

AIAA-2010-33

\section{CFD Models of a Serpentine Inlet, Fan, and Nozzle}

R.V. Chima, D.J. Arend, R.S. Castner, and J.W. Slater

Glenn Research Center, Cleveland, Ohio

P.P. Truax

Lockheed Martin Corporation, Fort Worth, Texas

Prepared for the

48th Aerospace Sciences Meeting

sponsored by the American Institute of Aeronautics and Astronautics

Orlando, Florida, January 4-7, 2010

National Aeronautics and

Space Administration

Glenn Research Center

Cleveland, Ohio 44135 


\section{Acknowledgments}

The authors would like to thank Dr. Daniel L. Tweedt of AP Solutions, Inc. for development and support of the AVCS and SYNCEX codes.

Trade names and trademarks are used in this report for identification only. Their usage does not constitute an official endorsement, either expressed or implied, by the National Aeronautics and Space Administration.

This work was sponsored by the Fundamental Aeronautics Program at the NASA Glenn Research Center.

Level of Review: This material has been technically reviewed by technical management.

Available from

NASA Center for Aerospace Information 7115 Standard Drive

Hanover, MD 21076-1320
National Technical Information Service 5301 Shawnee Road Alexandria, VA 22312 


\title{
CFD Models of a Serpentine Inlet, Fan, and Nozzle
}

\author{
R.V. Chima, D.J. Arend, R.S. Castner, and J.W. Slater \\ National Aeronautics and Space Administration \\ Glenn Research Center \\ Cleveland, Ohio 44135 \\ P.P. Truax (retired) \\ Lockheed Martin Corporation \\ Fort Worth, Texas 76101
}

\begin{abstract}
Several CFD codes were used to analyze the Versatile Integrated Inlet Propulsion Aerodynamics Rig (VIIPAR) located at NASA Glenn Research Center. The rig consists of a serpentine inlet, a rake assembly, inlet guide vanes, a 12-inch diameter tip-turbine driven fan stage, exit rakes or probes, and an exhaust nozzle with a translating centerbody. The analyses were done to develop computational capabilities for modeling inlet / fan interaction and to help interpret experimental data. Three-dimensional Reynolds averaged NavierStokes (RANS) calculations of the fan stage were used to predict the operating line of the stage, the effects of leakage from the turbine stream, and the effects of inlet guide vane (IGV) setting angle. Coupled axisymmetric calculations of a bellmouth, fan, and nozzle were used to develop techniques for coupling codes together and to investigate possible effects of the nozzle on the fan. RANS calculations of the serpentine inlet were coupled to Euler calculations of the fan to investigate the complete inlet / fan system. Computed wall static pressures along the inlet centerline agreed reasonably well with experimental data but computed total pressures at the aerodynamic interface plane (AIP) showed significant differences from the data. Inlet distortion was shown to reduce the fan corrected flow and pressure ratio, and was not completely eliminated by passage through the fan.
\end{abstract}

\section{Introduction}

A new facility for testing integrated inlet and fan systems has been developed at NASA Glenn Research Center (GRC). The facility is known as the Versatile Integrated Inlet Propulsion Aerodynamics Rig (VIIPAR). ${ }^{1}$ As shown in Fig. 1, the rig consists of a serpentine inlet, a rake assembly at the aerodynamic interface plane (AIP), inlet guide vanes (IGVs), a 12-inch diameter tip-turbine driven fan, exit rakes or probes, and an exhaust nozzle with a translating centerbody.

Checkout tests of the VIIPAR rig were made with the serpentine inlet replaced with an axisymmetric bellmouth. Static pressure measurements in the bellmouth were used with a calibration curve to determine the mass flow rate, and the exit total pressure rakes were used to determine the fan total pressure ratio. The fan maps obtained in this manner did not match the original vendor specs for the fan at the highest rotational speeds. In particular, the measured maximum flow rate was about nine percent lower than the maximum flow rate shown on the vendor specs.

CFD simulations were made of most of the components of the VIIPAR rig both to determine the cause of the discrepancy. Three-dimensional Navier-Stokes simulations were made of the fan unit to calculate the choking flow rate and the effects of blade untwist on that parameter. It was found that the rotor choked at the measured flow rate with a normal shock in the passage and that the original specs were probably in error. Leakage of high-energy turbine air into the fan flow path was also simulated computationally. These simulations showed that leakage could have a large impact on the fan map but probably was well controlled in the rig. Finally, coupled axisymmetric calculations were made of the bellmouth inlet, fan unit, and exhaust nozzle both to investigate overall system performance and also to develop computational capabilities for modeling inlet / fan interaction in general. The CFD calculations of the VIIPAR rig are described in this paper.

After questions about the maximum flow rate were resolved, the axisymmetric bellmouth was replaced with a high aspect ratio serpentine inlet designed by Lockheed Martin. The inlet used air jet vortex generator flow control devices to maintain flow quality and was thus referred to as the Active Inlet Flow Control (AIFC) inlet. The inlet was tested with and without flow control, but flow control results are not discussed in this paper. 
Several researchers have reported on similar inlets. Wendt ${ }^{2}$ tested two serpentine inlets at NASA GRC in 2002 and developed optimal flow control strategies for both vane vortex generators and micro jets. In that work the inlets were connected directly to an altitude exhaust line. Hamstra, et al. ${ }^{3}$ summarized Wendt's experimental work and compared it to CFD calculations done by Lockheed Martin. They concluded that turbulence models were unable to predict the extreme degree of separation in this type of inlet without flow control. Rabe, et al. ${ }^{4}$ tested an inlet similar to one of Wendt's at Virginia Tech in 2004. Here the inlet was connected to a plenum that was exhausted using a Honeywell F109 engine. In Ref. 5, Rabe et al. simulated angle of attack conditions by covering portions of the inlet face with screens and used a parallel compressor model to investigate axisymmetric bellmouth effects on engine stability. Kirk, et al. ${ }^{6}$ used a low-speed open loop wind tunnel to retest the inlet described by Hamstra, et al. ${ }^{3}$ They showed CFD calculations using two codes that predicted very different loss patterns at the AIP.

In the present work, the AIFC inlet was closely coupled to a fan simulator to investigate possible interaction between the components. Fully three-dimensional CFD calculations were made of the AIFC inlet coupled to the fan. The inlet calculations are described here in detail and compared to experimental data. Finally, the computed effects of inlet distortion on fan performance are described.

\section{VIIPAR Rig}

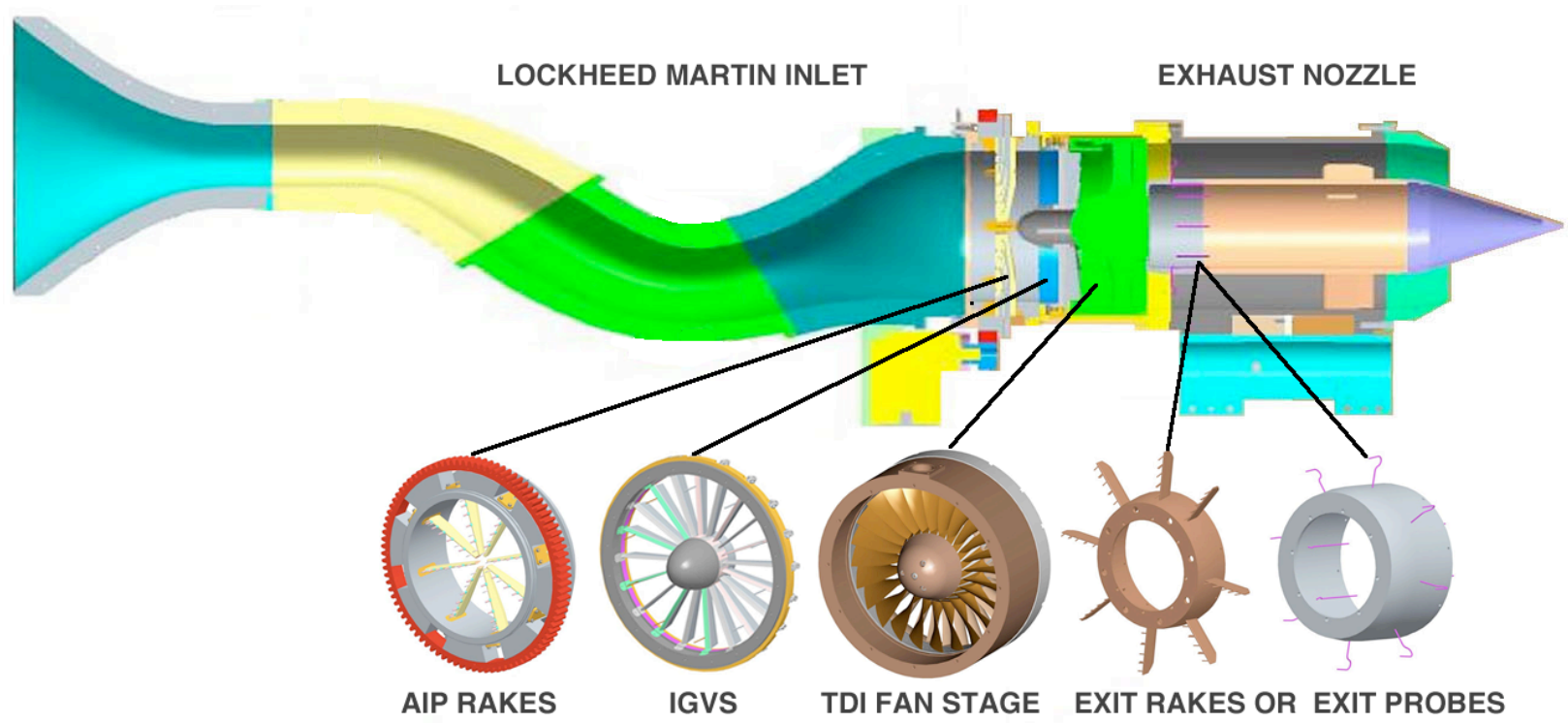

Figure 1. The Versatile Integrated Inlet Propulsion Aerodynamics Rig (VIIPAR).

The VIIPAR rig (Fig. 1) consists of the AIFC inlet, a rake assembly at the AIP, IGVs, a 12-inch diameter tipturbine driven fan, exit rakes or probes, and an exhaust nozzle with a translating centerbody.

The AIFC inlet consisted of a non-axisymmetric bellmouth followed by a serpentine duct. It was instrumented with 25 static pressure taps along the upper centerline, 26 static taps along the lower centerline, and eight static taps around the perimeter at the throat. The throat taps were used with a calibration curve to estimate the mass flow through the inlet.

A rotating array of eight total pressure rakes was located at the AIP to measure the inlet recovery and distortion patterns. Each rake had five dynamic total pressure probes located at the center of equal areas, following SAE ARP 1420 guidelines ${ }^{7}$. Each rake also had nine total pressure probes connected to a steady state data system. The rake assembly could be rotated in 15-degree increments to provide detailed maps of total pressure distortion at the AIP.

Twenty IGVs were located after the rake assembly to straighten the flow from the inlet. The vanes were split at mid chord with the front part fixed and the rear part hinged. They could be set to unload the rotor but were usually left in the straight position.

The fan simulator was a Tech Development Incorporated (TDI) Model 1109 unit originally designed in the 1970's for vertical short takeoff and landing (VSTOL) research. It had 24 rotor blades designed by Pratt and Whitney for a quiet fan design ${ }^{8}$. The original design was scaled from a tip diameter of $31 \mathrm{in.}$ to $12 \mathrm{in}$. for the TDI fan. Thirty-two stator blades were used to support the rotor bearing. The stator blades were also based on the Pratt and Whitney design but the number of blades was reduced from 64 to 32 with the solidity maintained. 
The rotor blades were pinned to a rotating shroud that had 120 small impulse turbine blades mounted on the outside to drive the rotor. Heated air drove the turbine to speeds up to $18,300 \mathrm{rpm}$. Teflon seals were used on either side of the shroud to minimize leakage of turbine drive air into the primary flow path. The turbine drive air passed through the turbine rotor, through straightening vanes located over the stators, and exhausted into the primary flow path just downstream of the stators. At the stator trailing edge the casing diameter expanded abruptly to 13.31 in. to accommodate the additional flow.

A stationary array of eight total pressure rakes with five probes apiece was located downstream of the stators to measure the performance of the isolated fan. When the AIFC inlet was attached these rakes were replaced with eight individual Pitot probes to avoid possible interaction with the inlet flow field. Unfortunately this made it impossible to determine the fan performance when the inlet was attached.

\section{CFD Codes}

\section{A. SWIFT}

SWIFT is a multi-block Reynolds averaged Navier-Stokes (RANS) code developed by Chima for analysis of turbomachinery blade rows. The code solves the Navier-Stokes equations on body-fitted grids using an explicit finite-difference scheme. Inviscid fluxes are discretized using the advective upwind splitting method (AUSM $\left.{ }^{+}\right)^{9}$. Viscous terms are included in the blade-to-blade and hub-to-tip directions, but neglected in the streamwise direction using the thin-layer approximation. The discretized equations are solved with a multistage Runge-Kutta scheme using a spatially varying time step and implicit residual smoothing to accelerate convergence. The flow equations and solution scheme are given in Ref. 10.

Turbulent flows are modeled using the Wilcox k- $\omega$ turbulence model ${ }^{11}$. The numerical implementation of the model was described for a two-dimensional case in Ref. 12.

For multistage turbomachinery SWIFT uses a mixing plane approach with steady characteristic boundary conditions written in terms of perturbations about the mean flow from the neighboring blade row ${ }^{13}$. This allows close spacing between the blade rows without forcing the solution to be axisymmetric. A mixed-out average is used to calculate the mean flow to insure conservation between the blade rows.

SWIFT was used to investigate the choking flow rate, the effects of blade untwist, and the effects of seal leakage in the VIIPAR fan stage. Typical calculations took several hours per case on a personal computer with 2 Intel Xeon CPUs operating at $3.8 \mathrm{GHz}$.

\section{B. Compressor Stall Code (CSTALL)}

CSTALL is a three-dimensional Euler code developed by Chima for predicting the effects of inlet distortion on turbomachinery performance and stability ${ }^{14}$. The code uses relatively coarse grids that do not resolve the blade profiles. It can be run quickly for the entire annulus and all blade rows. Blade row turning, loss, and deviation are modeled using body force terms that are formulated rigorously for a control volume around each blade row. The body force terms require input of unknown data at the leading and trailing edges of the blades. That data can be derived from Navier-Stokes calculations of the blades analyzed previously using SWIFT.

CSTALL was coupled with AVCS (described below) and run in an axisymmetric mode to predict the performance of the bellmouth, fan, and nozzle system. Axisymmetric cases took about 30 seconds. CSTALL was also coupled with WIND-US (described below) and run in a fully three-dimensional mode to investigate the effects of total pressure distortion from the AIFC inlet on the VIIPAR fan unit. These calculations took about 25 hours.

\section{Axisymmetric Viscous CFD Solver (AVCS)}

AVCS is an axisymmetric RANS code developed by Tweedt and Chima for analyzing flows in ducts ${ }^{15}$. The code solves the axisymmetric Navier-Stokes equations including the tangential momentum equation to predict the effects of swirl. Blockage terms are included that can be used to model the overall effects of struts in the duct. Like SWIFT, AVCS also uses the AUSM ${ }^{+}$upwind differencing scheme ${ }^{9}$ and the $\mathrm{k}-\omega$ turbulence $\operatorname{model}^{11,12}$.

\section{WIND-US}

WIND-US is a general purpose CFD code developed by the NPARC Alliance ${ }^{16}$, which consists of a group of researchers from the Air Force, NASA, and industry. The code includes many flow solvers and turbulence models. The Roe upwind scheme and the Spalart-Almaras turbulence model were used here to model the AIFC inlet. 


\section{E. Synchronized Data Exchange Code (SYNCEX)}

SYNCEX is a small code written in the C programming language by Dr. Daniel L. Tweedt of AP Solutions, Inc. It is used for coupling other CFD codes. It runs in the background and handles data communication, storage, and synchronization between the other codes. Subroutines that read and write interface boundary data to SYNCEX were added to all of the other codes used in this work to couple them with each other.

\section{Fan Calculations}

\section{A. Computational Grid}

The geometries for the bellmouth, flow path, and nozzle for the VIIPAR rig were obtained from original blueprints, which gave segments of the components as line segments, circles, ellipses, or discrete coordinates. Several points were generated along each segment, and then spline fit and reclustered.

The original VIIPAR rotor design was scaled down from a Pratt and Whitney design for a low-noise fan ${ }^{8}$. For the present work the rotor and stator blade section coordinates were obtained from the design report, staggered, and stacked on radial stacking axes. Stator coordinates were rescaled from 64 to 32 blades while keeping the solidity constant. IGV and rake coordinates were obtained from rig blueprints.

Computational grids for the fan unit were generated using the TCGRID turbomachinery grid code developed by Chima. C-type blade-to-blade grids were generated at a few spanwise locations using an elliptic grid generator. The $\mathrm{C}$-grids were reclustered spanwise using a hyperbolic tangent clustering function. Transfinite interpolation was used to generate an H-grid ahead of the IGV. Grids for the IGV, rotor, stator, and rake of the VIIPAR fan were generated separately and merged later. Each grid overlapped its neighbor by one cell.

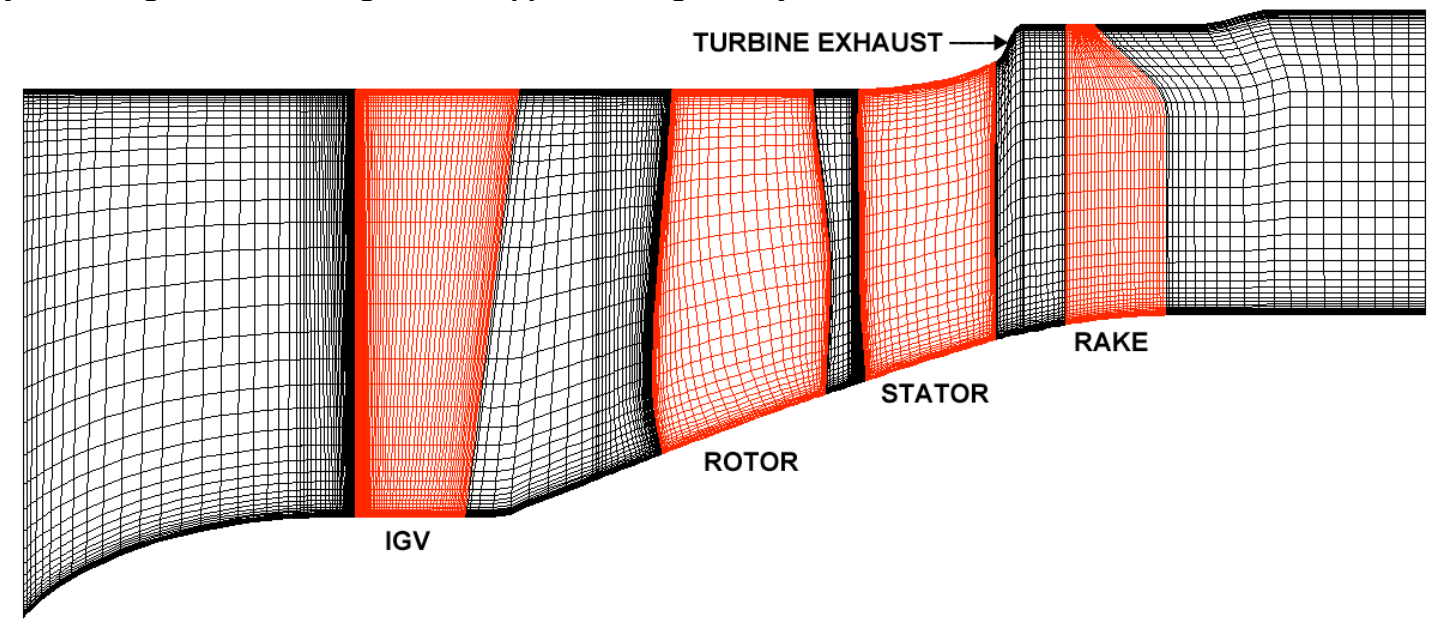

Figure 2. Meridional view of the 3-D grid for the VIIPAR fan.

\begin{tabular}{|l|c|r|r|}
\hline Region & Type & Points $(x, \theta, r)$ & Total points \\
\hline Upstream & $\mathrm{H}$ & $45 \times 30 \times 63$ & 85,050 \\
\hline IGV & $\mathrm{C}$ & $161 \times 42 \times 63$ & 426,006 \\
\hline Rotor & $\mathrm{C}$ & $193 \times 42 \times 63$ & 510,678 \\
\hline Stator & $\mathrm{C}$ & $193 \times 38 \times 63$ & 462,042 \\
\hline Rake & $\mathrm{C}$ & $193 \times 62 \times 63$ & 753,858 \\
\hline Total & & & $2,237,634$ \\
\hline
\end{tabular}

Table 1. 3-D grid sizes for the VIIPAR fan.

The initial checkout tests and early calculations of the VIIPAR rig were both done without the IGVs. Later experiments and calculations were done with the IGVs, rotor, stator, and rakes. The computational grid for the later configuration had five blocks. A meridional view is shown in Fig. 2 and grid sizes are given in Table 1. The grid spacing at the blade and endwalls was $2 \times 10^{-4}$ in., giving $\mathrm{y}^{+}=2$ to 4 at the first grid point off the walls. The total grid had 2.2 million points. 
The turbine mass flow was measured experimentally using a venturi in the feed line. At design speed it was 6.29 $\mathrm{lb} / \mathrm{sec}$. The turbine drive air exhausted into the primary flow path above the stators, where the measured exhaust total temperature was $492 \mathrm{R}$ (just above the freezing point of water). The turbine exhaust conditions were modeled computationally as an inflow boundary condition with the total temperature specified and the flow direction set to axial. The static pressure was extrapolated from the interior and the total pressure was adjusted iteratively to give the desired mass flow.

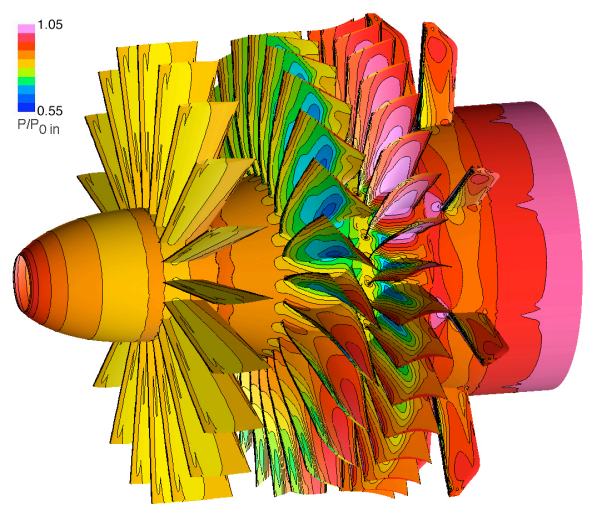

Figure 3. Computed static pressure ratios on the surface of the VIIPAR fan.

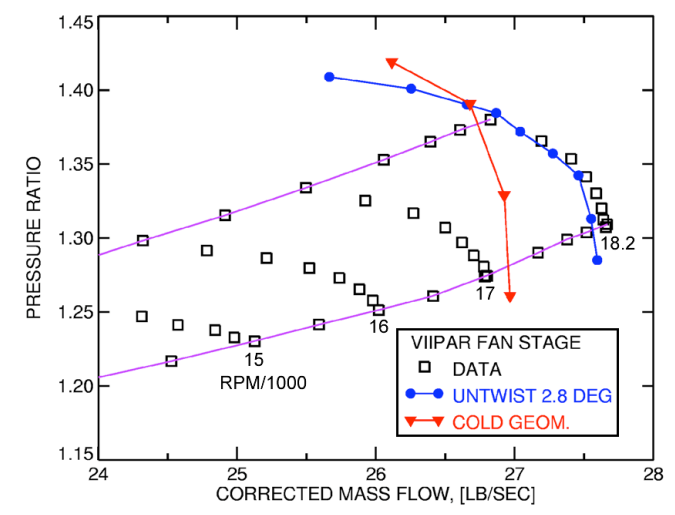

Figure 4. Measured and computed pressure ratios for the VIIPAR fan at 100 percent speed.

\section{B. Fan Performance}

SWIFT calculations for the VIIPAR fan rig took about 3.8 hours per case on two CPUs. Static pressure contours on the hub and blade surfaces are shown in Fig. 3.

Figure 4 compares measured and computed plots of total pressure ratio versus corrected mass flow. Measured data (squares) are shown for four speed lines nominally at 15,000 - 18,200 RPM, and along two operating lines at high and low flow (purple lines). Computations were made for the 18,200 RPM speed line. The maximum measured flow rate was $27.66 \mathrm{lb} / \mathrm{sec}$, which was about $2.5 \mathrm{lb} / \mathrm{sec}$ (nine percent) lower than the maximum flow rate shown on the original vendor specs for the fan. SWIFT usually predicts the maximum flow rate fairly accurately; however the initial calculations using the rotor design coordinates (red triangles labeled COLD GEOM) gave a maximum flow rate that was about $1 \mathrm{lb} / \mathrm{sec}$ lower than measured.

Although the rotor in the VIIPAR rig was shrouded, the blades were pinned to the shroud with a single pin near the stacking axis that left the blades free to untwist at high rotational speeds. The design report for the full-scale rotor gave an estimate for the maximum untwist stress on the rotor blade root at 110 percent speed. This stress was rescaled to design speed for the 12-inch rotor tested here and used to estimate that the blade tip could untwist by 2.8 degrees. The rotor grid was restaggered linearly from zero degrees at the hub to 2.8 degrees at the tip, and the pressure ratio characteristic was recalculated. The resulting pressure ratio characteristic (blue circles labeled UNTWIST 2.8 DEG) is still slightly low in maximum flow, but otherwise in good agreement with the data.

Experimental speed lines were generated by translating a variable area nozzle to throttle the fan. The low flow operating line on the left corresponds to the minimum nozzle area and is not stalled. The last computed point is the lowest stable operating point that could be computed, and suggests that the fan unit was never operated very close to stall. 


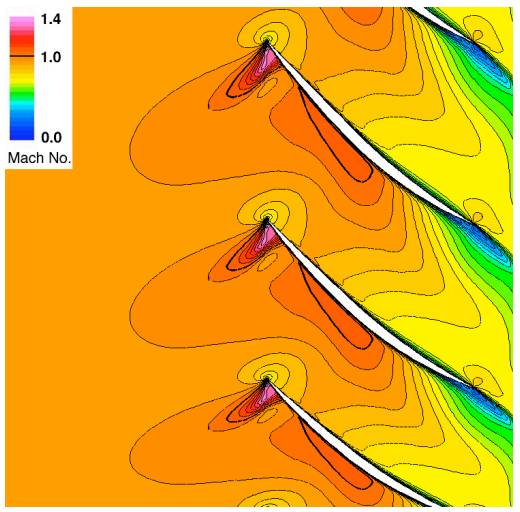

Near stall

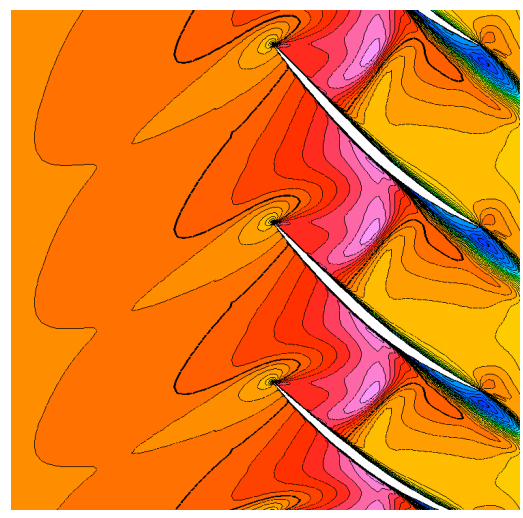

Choked

Figure 5. Relative Mach number contours for the VIIPAR rotor at 80 percent span.

Figure 5 shows relative Mach number contours in the rotor passage at 80 percent span. The heavy black line is the sonic line. The contours on the left are at an operating point near stall. The rotor tip Mach number is about 0.85 at design speed, which gives a transonic bubble on the suction surface terminated by a shock. The contours on the right are at the maximum flow point. They show that the flow accelerates through $\mathrm{M}=1.0$ near the leading edge, then decelerates through a normal shock within the passage. The sonic line extends from blade-to-blade over most of the span indicating that the flow in the rotor is choked. It is therefore unlikely that this rotor could reach the maximum flow shown on the vendor specs.

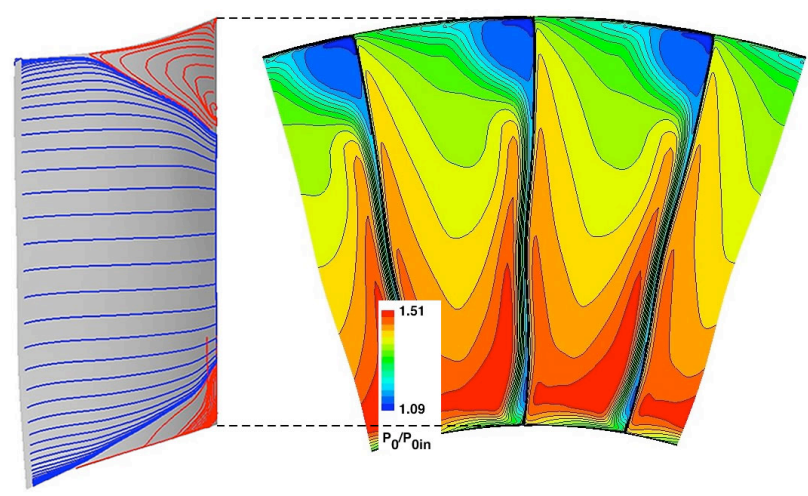

Figure 6. Left - streamlines near the stator suction surface. Right - Contours of PO/POin at the stator trailing edge.

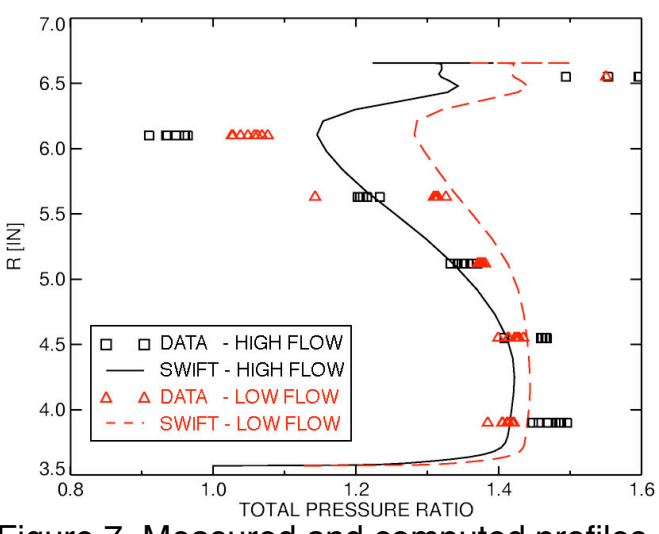

Figure 7. Measured and computed profiles of P0/POin downstream of the stator.

Stator calculations in Fig. 6 show a corner separation on the suction surface at the tip. On the left, near-surface streamlines show secondary flow (red) coming up from the hub and down from the tip. The secondary flow near the tip is recirculating from downstream, indicating a corner separation. On the right, total pressure ratio contours at the stator trailing edge show that the hub flow has little effect on the stator wake, but that the tip separation is quite large. The separation occurs because of the unusual expansion of the casing over the stator to meet the turbine exhaust. It was observed at all operating conditions. It reduces the overall stage pressure ratio but does not affect the maximum flow through the fan.

Figure 7 compares radial profiles of total pressure ratio at the rake face downstream of the stator. Two operating points are shown: one on the low flow operating line with the nozzle closed (red triangles,) and one on the high flow operating line with the nozzle open (black squares.) Most of the experimental data was taken with high (choked) flow. The eight rakes were equally spaced around the circumference and centered between the stators, yet there are significant differences between the rakes at a given radius. The computed profiles (lines) are in fair agreement with the rakes at the lower radii. At $\mathrm{R}=6.1$ inches, the measured total pressure ratios are much lower than the calculated values, suggesting that the actual stator corner separation could be larger than was indicated by the calculated results. The uppermost measurements at $\mathrm{R}=6.5$ inches were located in the turbine exhaust flow that was modeled 
computationally as an inflow boundary. The discrepancy in this region could thus be due to errors in modeling the turbine inflow.
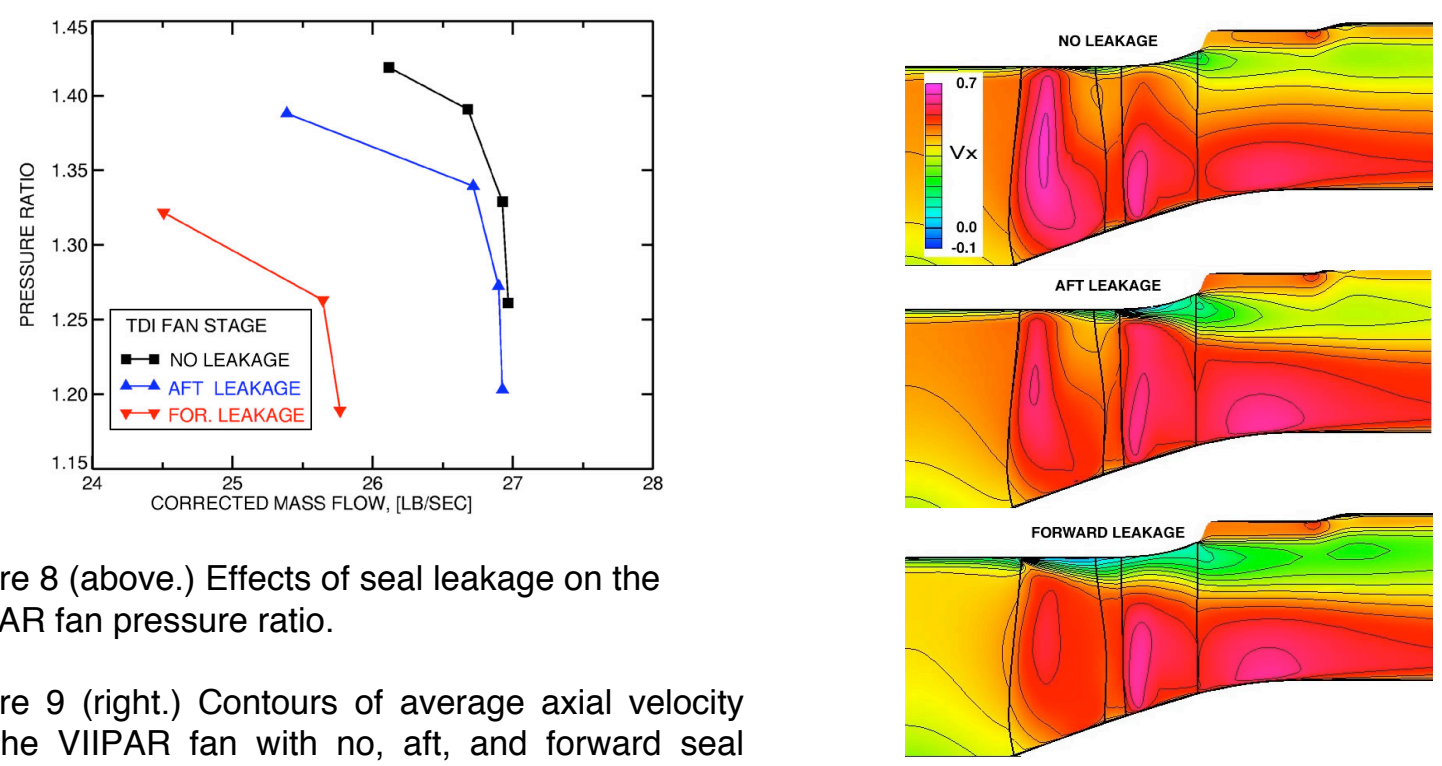

Figure 8 (above.) Effects of seal leakage on the VIIPAR fan pressure ratio.

Figure 9 (right.) Contours of average axial velocity for the VIIPAR fan with no, aft, and forward seal leakage.

\section{Effects of Seal Leakage}

In the fan unit, the rotor blades are pinned to a rotating shroud with a drive turbine mounted on the exterior. Teflon seals are used on either side of the shroud to minimize leakage of turbine drive air into the primary flow path. The measured gaps were 0.07 inches in front with a worn seal and 0.1 inches in back with no aft seal.

The effects of rotor shroud seal leakage were modeled computationally using an inflow boundary condition on the casing fore or aft of the rotor shroud. Leakage flow properties were estimated from the design conditions for the turbine drive air. The measured gaps were decreased 50 percent to simulate a discharge coefficient, which could be substantially in error. Predicted pressure ratio characteristics, with and without leakage, are shown in Fig. 8. The calculations were made using the design (cold) rotor geometry and without the IGVs or rakes, so they only give qualitative effects of the leakage.

The curve labeled NO LEAKAGE (black squares) is repeated from Fig. 4. The curve labeled AFT LEAKAGE (blue up-triangles) had leakage specified aft of the rotor shroud. The mass flow through this gap was about 0.85 $\mathrm{lb} / \mathrm{sec}$ and was usually not choked. Aft leakage reduced the choking flow and pressure ratio slightly. The curve labeled FOR. LEAKAGE (red down-triangles) had leakage specified forward of the rotor shroud. The mass flow through this gap was about $1.25 \mathrm{lb} / \mathrm{sec}$ and was always choked. Forward leakage had a large detrimental effect on the computed rotor performance. The actual leakage through the seals is probably much less than the computed leakage or the rotor would not perform as well as it does. Experimental paint flow visualization tests did not show evidence of leakage from the forward seal.

Contours of circumferentially averaged axial velocity with and without leakage are shown in Fig. 9. The top plot has no leakage and shows a small boundary layer on the rotating shroud over the rotor and the corner separation in the stator. The center plot has aft leakage that makes the stator separation worse and decreases the overall stage pressure ratio. The bottom plot has forward leakage that creates a large blockage in the rotor, thereby reducing the maximum flow. 


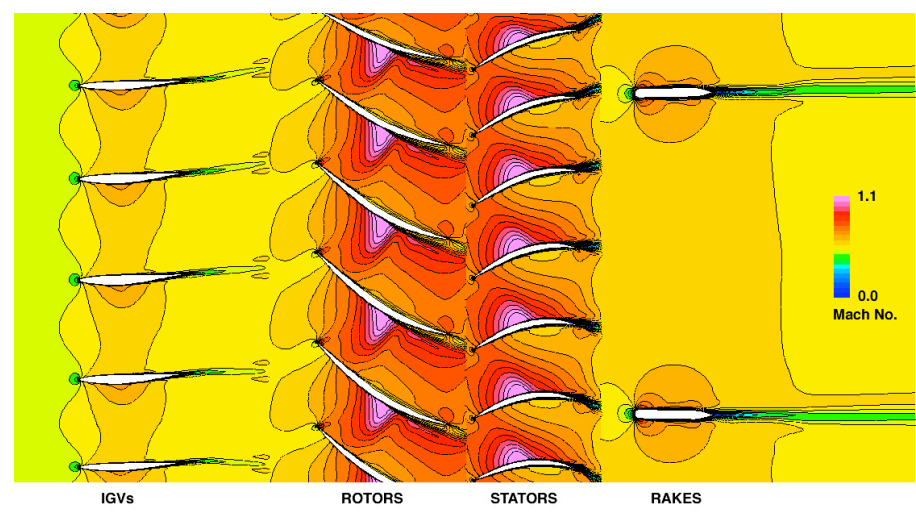

Figure 10. Absolute Mach number contours near the tip of the fan with the IGVs set to 6 degrees.

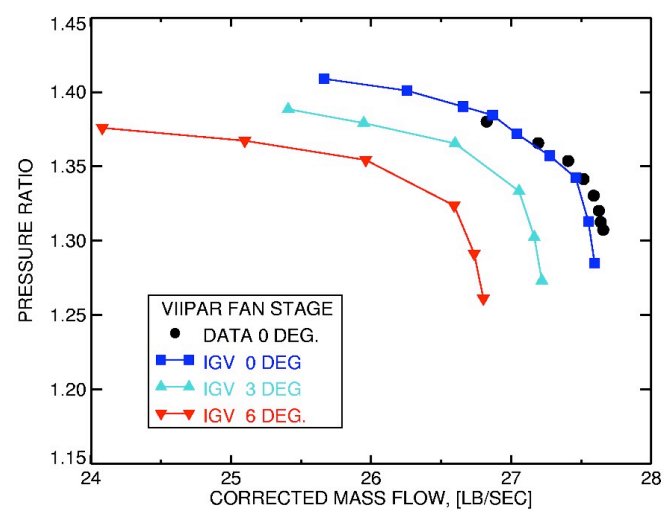

Figure 11. Effect of IGV setting angle on pressure ratio of the VIIPAR fan.

\section{Effects of Inlet Guide Vanes}

Inlet guide vanes were installed in the VIIPAR rig to straighten the flow from the AIFC inlet. They were usually set at zero degrees, although a few tests were run with them set to three or six degrees.

The vanes were split at mid chord with the front part fixed and the rear part hinged. Deflection was modeled computationally by regridding the deflected vanes. Figure 10 shows absolute Mach number contours near the casing with the IGVs set at six degrees. At that deflection, the pressure surface of the vanes becomes almost straight. The vanes deflect the flow in the direction of rotor rotation, which reduces the incidence on the rotors and reduces the blade loading and pressure ratio accordingly.

Figure 11 shows the effect of IGV setting angle on the fan pressure ratio. The curve for zero degrees deflection is repeated from Fig. 4. Deflecting the IGVs reduces the flow rate, pressure ratio, and stall point. Six degrees of deflection reduces the choking flow rate by almost $1 \mathrm{lb} / \mathrm{sec}$.

\section{Coupled Bellmouth / Fan / Nozzle Calculations}

Checkout tests of the VIIPAR rig were made with an axisymmetric bellmouth instead of the AIFC inlet. Coupled axisymmetric calculations were carried out for the entire VIIPAR rig in that configuration including the bellmouth, fan, and nozzle. These calculations were used mainly to develop new modeling capability rather than to predict performance of the VIIPAR rig. The bellmouth and nozzle were modeled using the viscous AVCS code. The fan unit was modeled using the inviscid CSTALL code. The codes were coupled at interface planes on either side of the fan using SYNCEX. Computational grid sizes for the three components are given in Table 2 below.

\begin{tabular}{|l|l|c|r|}
\hline Region & Type & Points $(x, r)$ & Total points \\
\hline Inlet & viscous & $147 \times 51$ & 7,497 \\
\hline Fan & inviscid & $175 \times 21$ & 3,675 \\
\hline Nozzle & viscous & $133 \times 45$ & 5,985 \\
\hline Total & & & 17,157 \\
\hline
\end{tabular}

Table 2. Axisymmetric grid sizes for the VIIPAR rig.

Three struts in the nozzle were modeled using axisymmetric blockage terms in AVCS that modeled the circumferential area reduction but not the viscous effects of the struts.

CSTALL was used to model the fan unit. CSTALL is an inviscid (Euler) code that includes body force terms that produce the turning and entropy rise within the fan. The code requires input of spanwise profiles of these quantities at blade leading and trailing edges. These profiles were generated automatically by SWIFT during calculation of the baseline performance map in Fig. 4. For axisymmetric cases, CSTALL closely reproduces the input profiles. For cases with circumferential distortion, CSTALL allows each circumferential grid plane to operate on a different point of the performance map, similar to a parallel compressor model. 


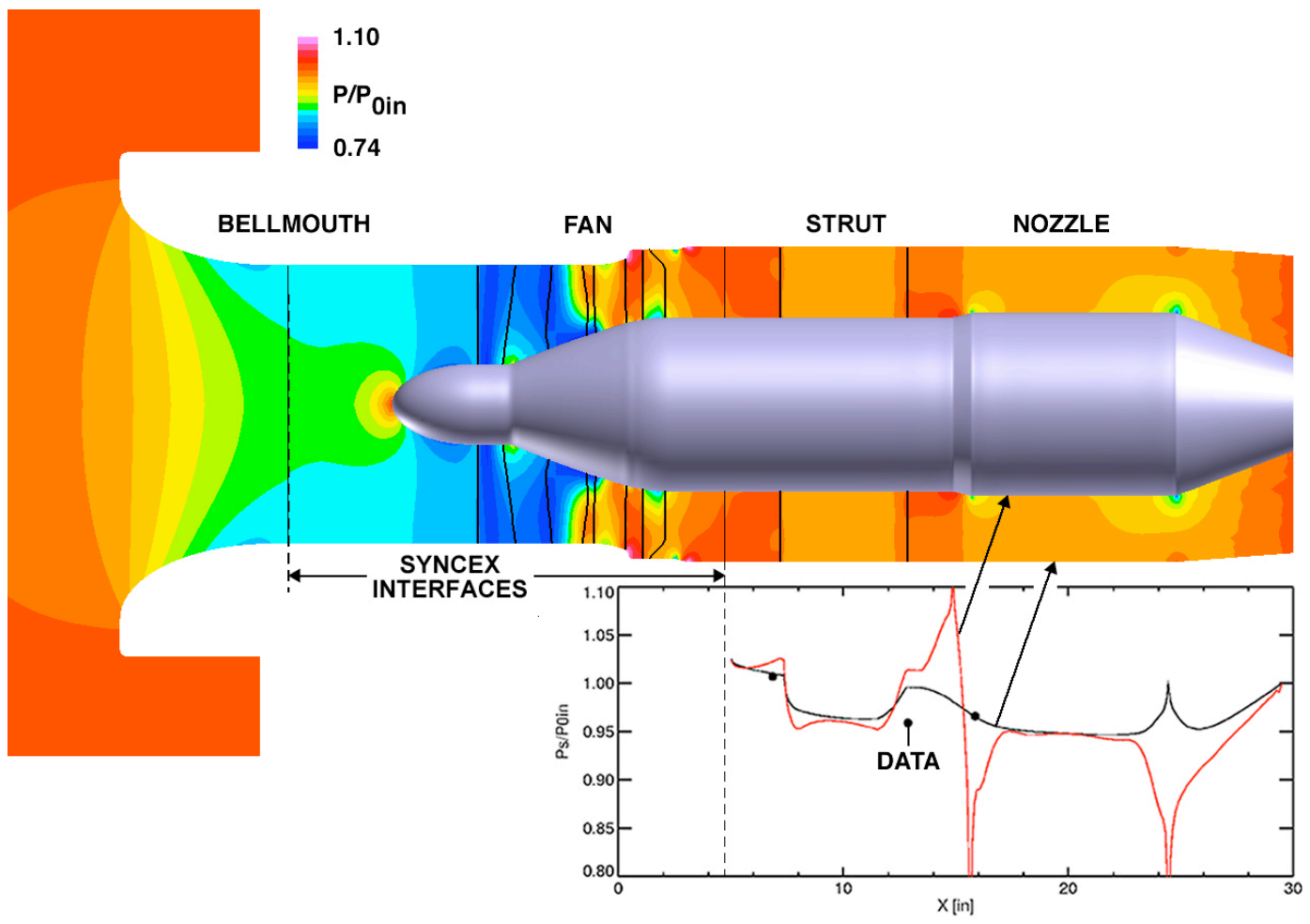

Figure 12. Top - Static pressure ratio contours in the bellmouth, fan, and nozzle of the VIIPAR rig. Bottom - Comparison of computed and measured static pressures in the nozzle.

Coupled calculations of the three components took only 70 seconds per case. Typical results are shown for a case near choke in Fig. 12 where static pressure ratio is shown through the entire VIIPAR rig. Static pressure ratio through the nozzle is plotted directly underneath. Static taps on the casing showed a significant pressure drop through the nozzle. The calculations match the limited data fairly well and show that the pressure drop is due to blockage by the struts and the translating centerbody, but has little effect on the fan.

\section{Coupled Inlet / Fan Calculations}

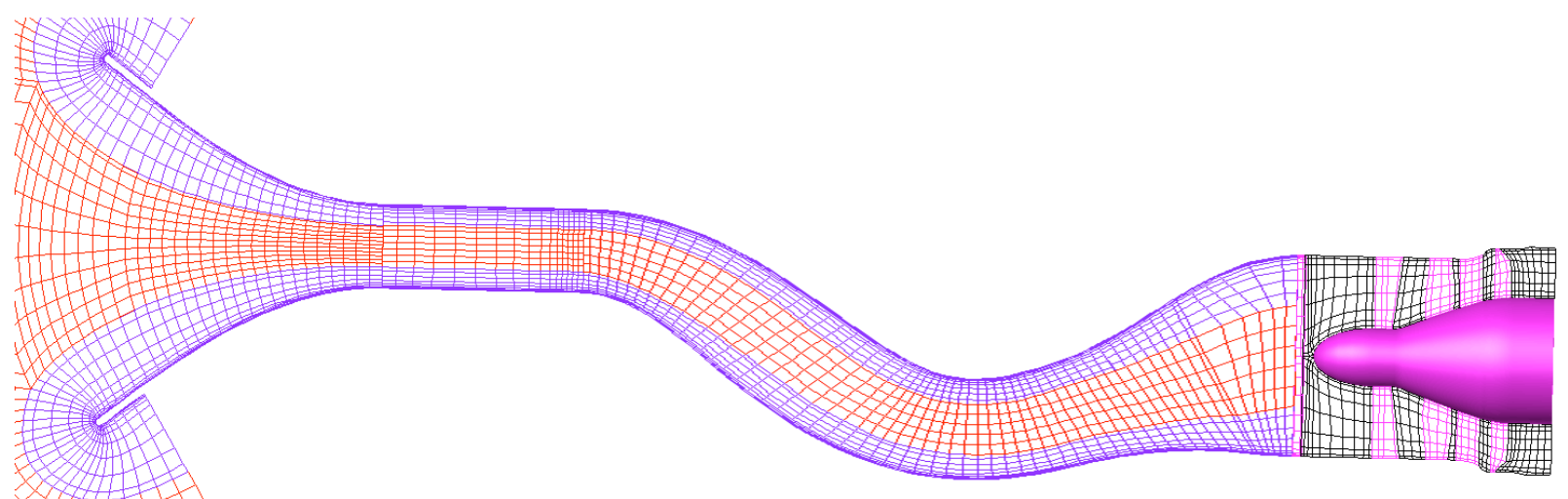

Figure 13. Computational grid along the centerline of the AIFC inlet and VIIPAR fan.

\section{E. Computational Grid}

The AIFC inlet had an integral, non-axisymmetric bellmouth attached to the upstream end of the serpentine duct. Dr. John Slater developed the computational grid for the inlet using the commercial Gridgen grid generation software. A section through the symmetry plane of the grid is shown in Fig. 13. The grid included a region of external flow, the non-axisymmetric bellmouth, and the AIFC inlet duct. Cross-sectional planes through the grid had 
a ring of cells around the circumference (shown in blue) to capture wall boundary layers, matched to an H-grid in the center (red) for the core flow. The wall spacing was 0.0001 inches, giving $\mathrm{y}^{+}=1$ to 2 at the first grid point off the walls. The grid was symmetric from side to side but the entire flow was computed to allow for asymmetries at the fan face. The inlet grid had 62 blocks with a total of 4.48 million cells.

Fan calculations were done with the inviscid CSTALL code described earlier. The fan grid had 163 points in $\mathrm{x}$, 32 points in $\mathrm{r}$, and 120 points in $\theta$ for a total of 625,920 cells. The overall grid for the inlet and fan had 5.1 million cells. A short cylindrical grid block was used to match the inlet grid to the fan grid at the AIP, where the grids were point-matched in $\theta$ but interpolated in $\mathrm{r}$.

\section{F. Inlet Performance}

Inlet calculations were run with the WIND-US code using Roe upwind differencing and the Spalart-Almaras turbulence model. Inlet flow control was not modeled in these calculations. The WIND-US calculations were coupled to the CSTALL calculations at each iteration using SYNCEX. The calculations were typically run 3,000 iterations per case at a Courant number of 2.5. The total pressure recovery at the AIP and fan pressure and temperature ratios were monitored for convergence. Six operating points along a fan speed line were computed by varying the fan exit pressure.

The calculations were run on a PC with two Xeon CPUs running at $3.8 \mathrm{GHz}$, and took about 25 hours per case. The viscous inlet calculations took about 95 percent of the CPU time. Normally the inlet calculations would be spread over many more CPUs to reduce the elapsed time, but this was not done for these preliminary calculations.

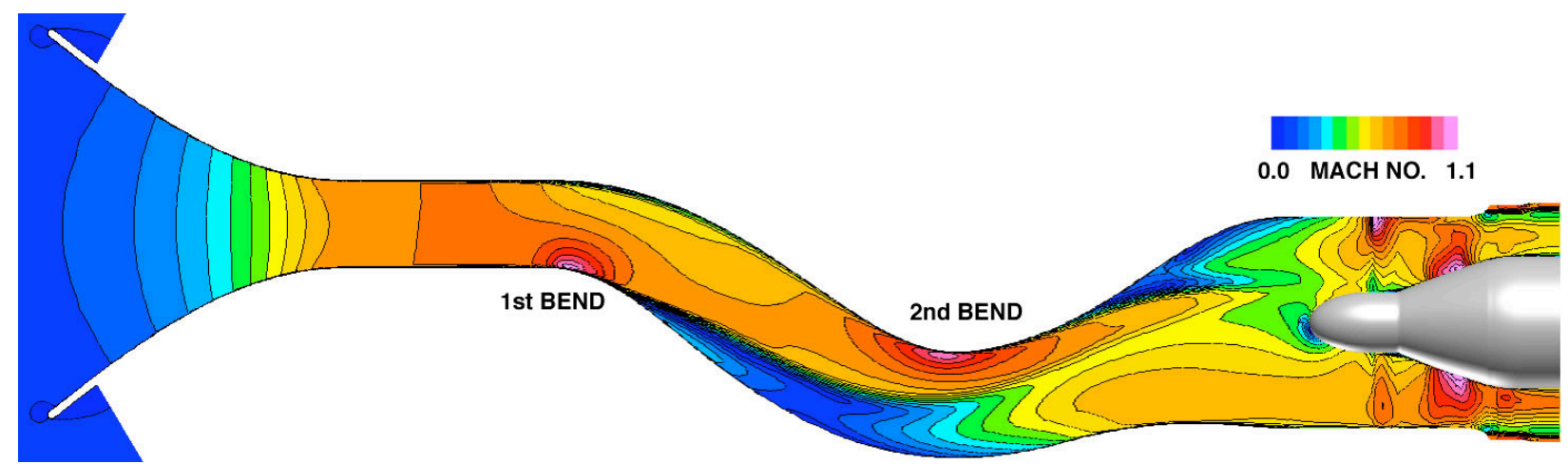

Figure 14. Mach number contours along the centerline plane of the AIFC inlet and fan.

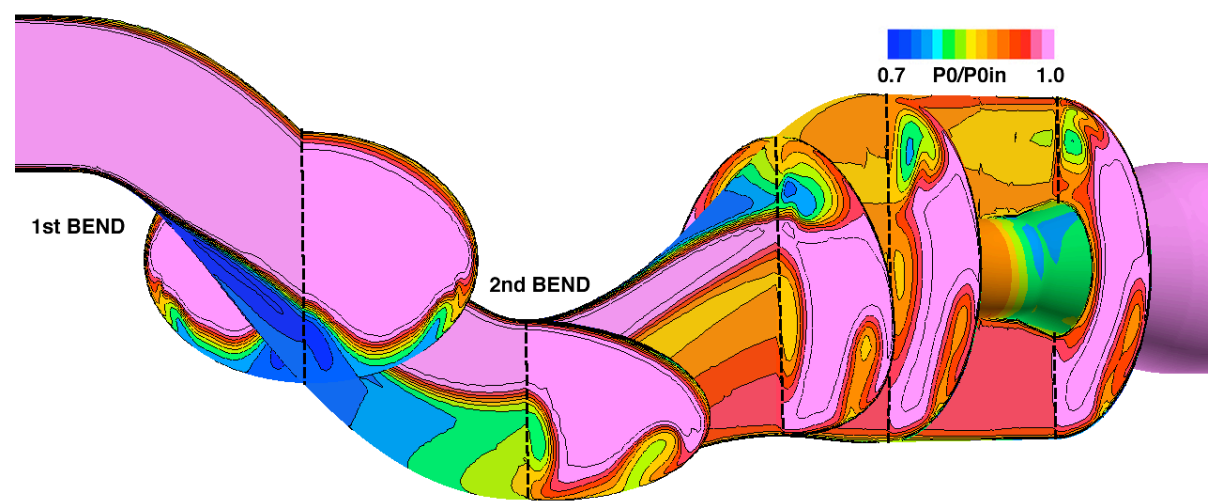

Figure 15. Total pressure ratio contours in the AIFC inlet.

Figure 14 shows computed Mach number contours along the center plane of the AIFC inlet and fan. The freestream Mach number was 0.05 . The flow accelerates to $\mathrm{M} \approx 0.6$ at the throat and reaches sonic conditions at the first bend on the lower wall, where the flow separates. The flow also separates on the upper wall somewhat after the second bend. Total pressure contours in the AIFC inlet shown in Figure 15 show how the separated flow develops into the secondary flow patterns seen at the AIP. Separated flow from the center of the first bend migrates to the center of the duct and eventually hits the bullet nose on the fan rig. Separated flow from the sides of the first bend 
form vortices that remain near the sidewalls all the way to the AIP. Separated flow from the second bend rolls up into a pair of counter-rotating vortices at the top of the AIP.

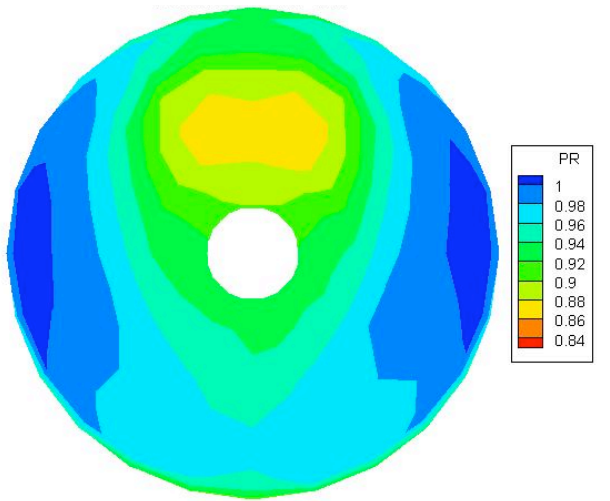

Measured, $\mathrm{PR}=0.952$

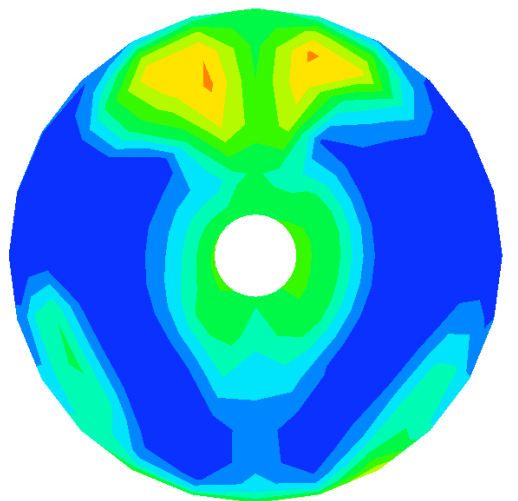

Computed, PR $=0.966$

Figure 16. Measured and computed total pressure ratio contours at the AIP.

Figure 16 compares measured and computed total pressure contours at the AIP. Pressures were measured using eight rakes (every 45 degrees) with nine probes radially per rake. The rake assembly was rotated in three 15 degree increments to give a total of $8 \times 9 \times 3=216$ measurement points on the AIP plane. The area-averaged measured recovery was 0.952 and the computed recovery was $0.966-1.4$ points too high. The computed contours shown above were plotted on a limited grid that approximated the measurement locations. The measured and computed patterns show two major differences. First, the region of low recovery in the center of the duct is much broader in the measurements than in the computations. Second, the computations show weak vortices along the sidewalls that do not appear in the measurements at all, and separate vortices at the top of the duct that appear to be merged in the measurements. These differences suggest that flow separation or dissipation of the resulting vortices is under predicted in the computations. Hamstra, et al. ${ }^{3}$ showed similar under prediction of recovery in a related inlet, and attributed it to inability of the turbulence models to predict the extreme separation in the duct. However, it is possible that the measured recoveries could be in error due to flow angularity. The combination Prati Pitot pressure probes used at the AIP were shown in Ref. 17 to measure about a point low at a pitch angle of 30 degrees. The computed flow angles in the top part of the duct varied over \pm 30 degrees, suggesting that the recoveries measured near the top of the duct could be low.

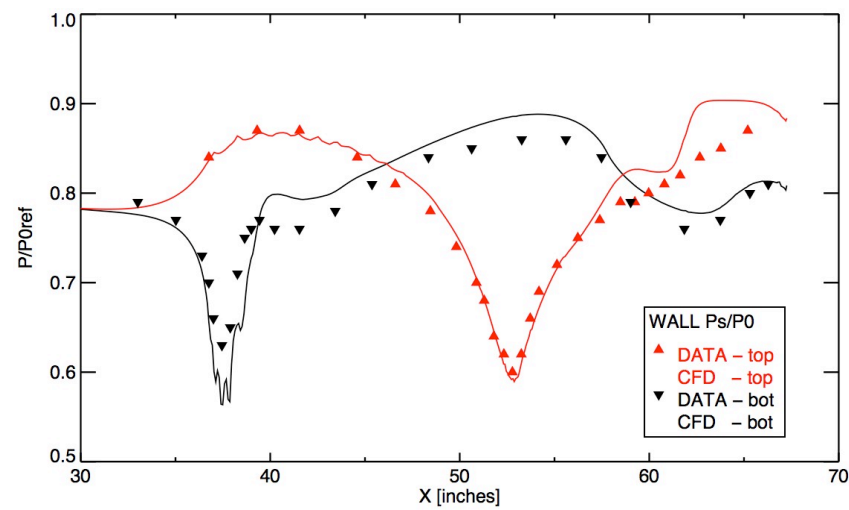

Figure 17. Measured and computed wall static pressures on the centerline of the AIFC inlet.

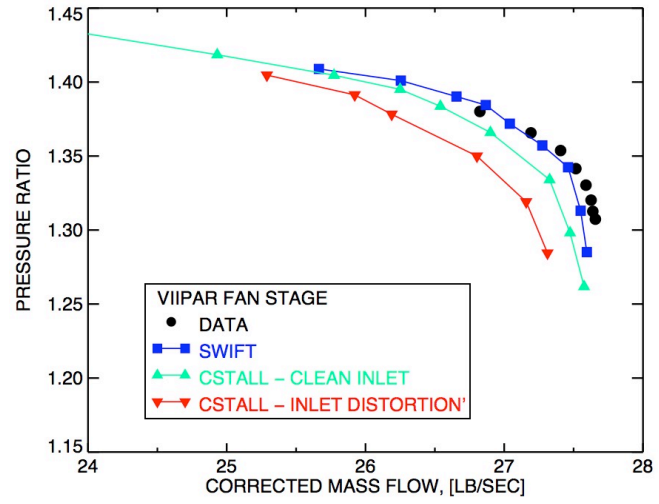

Figure 18. Effect of inlet distortion on fan pressure ratio.

Measured and computed wall static pressures on the centerline of the AIFC inlet are compared in Fig. 17. Pressures on the upper wall of the duct (red up-triangles) agree well up to the second bend near $\mathrm{x}=58$ where the computed flow separates and the pressure distribution flattens out abruptly. The measurements show a similar but less abrupt trend. Computed pressures on the lower wall (black down-triangles) are similar to the data but are a little too low in the first bend at $x=37$ and a little too high thereafter. Again this suggests that the computed separation is under predicted in both bends. 


\section{G. Effects of the Inlet Flow on the Fan}

Computed and measured fan pressure ratios are plotted against fan corrected mass flow in Fig. 18. The measured data (black dots) and SWIFT solutions (blue squares) from Fig. 4 are shown for reference. CSTALL solutions for clean inflow are shown by green up-triangles. The CSTALL solutions were calibrated using data from the SWIFT solutions and should agree with those solutions identically. However, for the VIIPAR rig it was difficult to separate the stator exit flow from the turbine exhaust. This led to errors in modeling the stator losses and caused the error in overall pressure ratio shown in Fig. 18. The coupled inlet/fan solutions (red down-triangles) show a 1.7 percent loss in corrected flow and a 3 percent loss of fan pressure ratio due to inlet distortion.

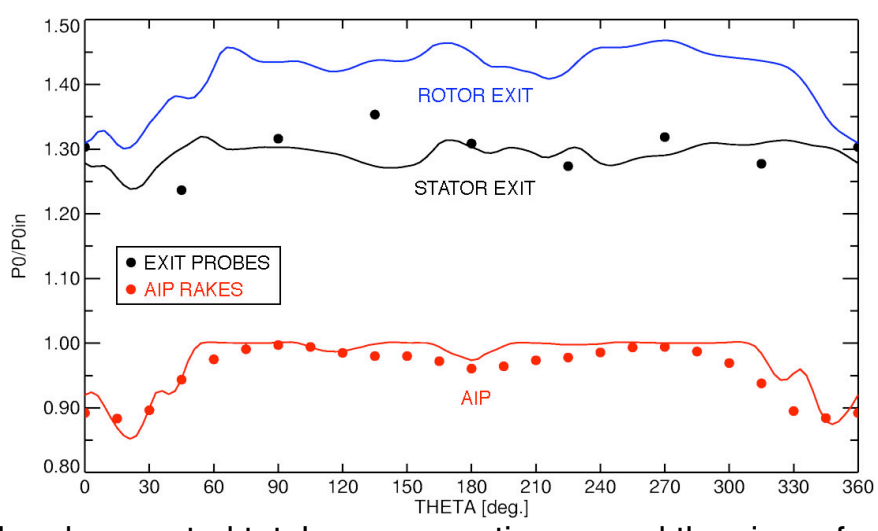

Figure 19. Measured and computed total pressure ratios around the circumference at mid span.

The inlet tests were performed with the fan exit rakes replaced by individual Pitot probes at mid span, so it was not possible to measure the fan pressure ratio during inlet tests. Figure 19, however, compares measured and computed circumferential distributions of total pressure ratio at mid span. At the AIP (red) the predicted total pressure ratios are slightly higher than the measured values, consistent with the higher overall predicted recovery. Here the average predicted pressure ratio was 0.974 and the average measured pressure ratio was 0.956 . There is no data at the rotor exit (blue) but the average predicted pressure ratio was 1.416. At the stator exit (black) the average predicted pressure ratio was 1.292 and the average measured pressure ratio was in good agreement at 1.299. The predictions show that the distortion is not completely eliminated by the fan. There is considerable scatter in the exit probe data that could be due to distortion, although the exit rake data shown in Fig. 7 also showed some scatter when the fan was tested with the axisymmetric bellmouth.

The SWIFT solutions predict stall at a flow rate of about $25.6 \mathrm{lb} / \mathrm{sec}$, but the VIIPAR fan was never stalled and the experimental stall point is unknown. The CSTALL solutions do not predict stall for this case - converged solutions can be obtained at very low flow rates. In Ref. 14, CSTALL was able to predict the stall point in a transonic compressor, but it is not known why it fails for this fan.

\section{Summary and Conclusions}

Several CFD codes were used to analyze the Versatile Integrated Inlet Propulsion Aerodynamics Rig (VIIPAR) located at NASA GRC. The rig consists of the Active Inlet Flow Control (AIFC) serpentine inlet, a rake assembly at the aerodynamic interface plane, inlet guide vanes, a 12-inch diameter tip-turbine driven fan stage, and an exhaust nozzle with a translating centerbody. The analyses were done to develop computational capabilities for modeling inlet / fan interaction and to help interpret experimental data.

Experimental measurements had shown that the maximum flow rate through the fan was about $2.5 \mathrm{lb} / \mathrm{sec}$ less than that shown on the original vendor specifications. Navier-Stokes calculations with the SWIFT code showed that the maximum flow through the rig was limited by choking due to a shock in the rotor and suggested that the specifications were in error. Calculations using the design rotor coordinates under predicted the choking flow. Estimated stresses suggested that the rotor could untwist by 2.8 degrees at the tip, and CFD calculations with the untwisted rotor showed good agreement with the measured performance.

SWIFT calculations also showed that a corner separation in the stator reduced the pressure ratio of the rig. The separation is due to a casing expansion used to mate the fan flow path with the exhaust from the tip turbine. The separation reduces the overall performance of the rig but does not limit the maximum flow. 
Simulations were made of leakage from the turbine stream through the seals fore and aft of the rotor shroud. These simulations showed that the forward seal is very important for maximum flow and pressure ratio, and that the aft seal is less important.

Inlet guide vanes in the VIIPAR rig were used to straighten the flow from the serpentine inlet. They were usually set at zero degrees, although a few tests were run with them deflected. Calculations were made with the IGVs deflected three and six degrees in the direction of rotor rotation. The calculations showed that deflecting the IGVs reduces the flow rate, pressure ratio, and stall point. Six degrees of deflection reduced the choking flow rate by almost $1 \mathrm{lb} / \mathrm{sec}$.

Axisymmetric calculations were made of the entire rig including an axisymmetric bellmouth inlet, the fan unit, and the nozzle. The AVCS RANS code was used for the bellmouth and nozzle, and the CSTALL Euler code was used for the fan unit. The SYNCEX code developed by Dr. Daniel Tweedt was used to couple the codes. These calculations were mostly used to test the code coupling methodology, but did show that the measured pressure drop through the nozzle is due primarily to geometric effects of the struts and translating centerbody.

Finally, full 3-D calculations were made of the AIFC inlet and VIIPAR fan using the WIND-US RANS code for the inlet coupled to CSTALL for the fan. The AIFC inlet calculations showed how separations in the bends of the inlet develop into the total pressure patterns measured at the AIP. Computed pressures along the inlet centerline agreed reasonably well with measured values, but there were significant discrepancies in the predicted recovery and the distortion patterns at the AIP. The discrepancies were probably due to under prediction of the two separation regions in the inlet. The distortion reduced the corrected flow and pressure ratio of the fan and was not entirely eliminated after passing through the fan.

\section{References}

1. Arend, D. J., Castner, R. S., and Frate, F. C., "A Low Cost, Compact and Versatile Rig for Integrated Inlet and Propulsion Systems Research,” AIAA Paper 2006-1313, Jan. 2006.

2. Wendt, B. J., "The Development of Vortex-Induced Flow Control for Ultra-Compact Serpentine Inlet Ducts," NASA CR2002-211986, Nov. 2002.

3. Hamstra, J. W., Miller, D. N., Truax, P. P., Anderson, A. A., and Wendt, B. J., “Active Inlet Flow Control Technology Demonstration," $22^{\text {nd }}$ Internal Council of Aeronautical Sciences, ICAS Paper 6112, Aug. 2000.

4. Rabe, A., Ölçmen, S., Anderson, J., Burdisso, R., and Ng., W., "A Facility for Active Flow Control Research in Serpentine Inlets," AIAA Paper 2002-0510, Jan. 2002.

5. Rabe, A., Ng, W., and Burdisso, R., "Effectiveness of a Serpentine Inlet Flow Control Technique at Design and Off-Design Simulated Flight Conditions," ASME Paper GT2004-53475, June, 2004.

6. Kirk, A. M., Kumar, A., Gargoloff, J. I., Rediniotis, O. K., and Cizmas, P. G. A., "Numerical and Experimental Investigation of a Serpentine Inlet Duct," AIAA Paper 207-842, Jan. 2007.

7. "Gas Turbine Engine Inlet Flow Distortion Guidelines," Aerospace Recommended Practice 1420 - Revision B, Society of Automotive Engineers, Feb. 2002.

8. Monsarrat, N. T., Keenan, M. J., and Tramm, P. C., "High-Loading Low-Speed Fan Study," NASA CR-72536, July, 1969.

9. Chima, R. V. and Liou, M.-S., "Comparison of the AUSM ${ }^{+}$and H-CUSP Schemes for Turbomachinery Applications," AIAA Paper AIAA-2003-4120. Also NASA TM-2003-212457.

10. Chima, R. V., "Viscous Three-Dimensional Calculations of Transonic Fan Performance," in CFD Techniques for Propulsion Applications," AGARD Conference Proceedings No. CP-510, AGARD, Neuilly-Sur-Seine, France, Feb. 1992, pp. 21-1 to 21-19. Also NASA TM-103800.

11. Wilcox, D. C., Turbulence Modeling for CFD, Third Edition, DCW Industries, Inc., La Canada, CA, 2006.

12. Chima, R. V., "A k- $\omega$ Turbulence Model for Quasi-Three-Dimensional Turbomachinery Flows," AIAA Paper 96-0248. Also NASA TM-107051.

13. Chima, R. V., "Calculation of Multistage Turbomachinery Using Steady Characteristic Boundary Conditions," AIAA Paper 98-0968, Jan. 1998. Also NASA TM-1998-206613.

14. Chima, R. V., “A Three-Dimensional Unsteady CFD Model of Compressor Stability,” ASME Paper GT2006-90040, May. 2006. Also NASA TM-2006-214117.

15. Tweedt, D. L. and Chima, R. V., "Rapid Numerical Simulation of Viscous Axisymmetric Flows," AIAA Paper 96-0449, Jan. 1996. Also NASA TM-107103.

16. Bush, R. H., Power, G. D., and Towne, C. E., "WIND: The Production Flow Solver of the NPARC Alliance," AIAA Paper 98-0935, 1998.

17. Arend, David J., and Saunders, John D., "An Experimental Evaluation of the Performance of Two Combination Pitot Pressure Probes,” AIAA Paper 2009-1073, Jan. 2009. 


\begin{tabular}{|c|c|c|c|c|c|}
\hline \multicolumn{5}{|c|}{ REPORT DOCUMENTATION PAGE } & $\begin{array}{c}\text { Form Approved } \\
\text { OMB No. 0704-0188 }\end{array}$ \\
\hline \multicolumn{6}{|c|}{ 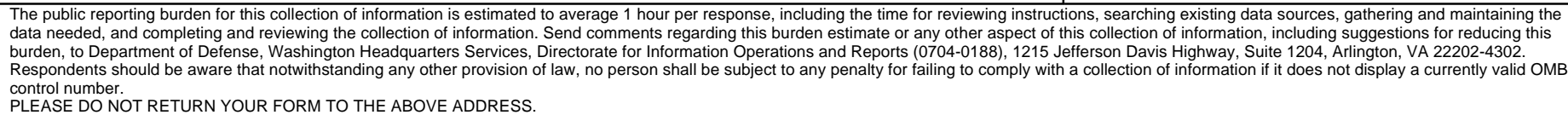 } \\
\hline \multicolumn{2}{|c|}{$\begin{array}{l}\text { 1. REPORT DATE (DD-MM-YYYY) } \\
01-05-2010\end{array}$} & \multicolumn{3}{|c|}{$\begin{array}{l}\text { 2. REPORT TYPE } \\
\text { Technical Memorandum }\end{array}$} & 3. DATES COVERED (From - To) \\
\hline \multirow{3}{*}{\multicolumn{5}{|c|}{$\begin{array}{l}\text { 4. TITLE AND SUBTITLE } \\
\text { CFD Models of a Serpentine Inlet, Fan, and Nozzle }\end{array}$}} & 5a. CONTRACT NUMBER \\
\hline & & & & & 5b. GRANT NUMBER \\
\hline & & & & & 5c. PROGRAM ELEMENT NUMBER \\
\hline \multirow{3}{*}{\multicolumn{5}{|c|}{$\begin{array}{l}\text { 6. AUTHOR(S) } \\
\text { Chima, R., V.; Arend, D., J.; Castner, R., S.; Slater, J., W.; Truax, P., P. }\end{array}$}} & 5d. PROJECT NUMBER \\
\hline & & & & & 5e. TASK NUMBER \\
\hline & & & & & $\begin{array}{l}\text { 5f. WORK UNIT NUMBER } \\
\text { WBS 984754.02.07.03.13.02 }\end{array}$ \\
\hline \multicolumn{5}{|c|}{$\begin{array}{l}\text { 7. PERFORMING ORGANIZATION NAME(S) AND ADDRESS(ES) } \\
\text { National Aeronautics and Space Administration } \\
\text { John H. Glenn Research Center at Lewis Field } \\
\text { Cleveland, Ohio 44135-3191 }\end{array}$} & $\begin{array}{l}\text { 8. PERFORMING ORGANIZATION } \\
\text { REPORT NUMBER } \\
\text { E-17285 }\end{array}$ \\
\hline \multirow{2}{*}{\multicolumn{5}{|c|}{$\begin{array}{l}\text { 9. SPONSORING/MONITORING AGENCY NAME(S) AND ADDRESS(ES) } \\
\text { National Aeronautics and Space Administration } \\
\text { Washington, DC 20546-0001 }\end{array}$}} & $\begin{array}{l}\text { 10. SPONSORING/MONITOR'S } \\
\text { ACRONYM(S) } \\
\text { NASA }\end{array}$ \\
\hline & & & & & $\begin{array}{l}\text { 11. SPONSORING/MONITORING } \\
\text { REPORT NUMBER } \\
\text { NASA/TM-2010-216349 }\end{array}$ \\
\hline \multicolumn{6}{|c|}{$\begin{array}{l}\text { 12. DISTRIBUTION/AVAILABILITY STATEMENT } \\
\text { Unclassified-Unlimited } \\
\text { Subject Category: } 07 \\
\text { Available electronically at http://gltrs.grc.nasa.gov } \\
\text { This publication is available from the NASA Center for AeroSpace Information, 443-757-5802 }\end{array}$} \\
\hline \multicolumn{6}{|c|}{$\begin{array}{l}\text { 13. SUPPLEMENTARY NOTES } \\
\text { P.P. Truax, retired. }\end{array}$} \\
\hline \multicolumn{6}{|c|}{$\begin{array}{l}\text { 14. ABSTRACT } \\
\text { Several computational fluid dynamics (CFD) codes were used to analyze the Versatile Integrated Inlet Propulsion Aerodynamics Rig } \\
\text { (VIIPAR) located at NASA Glenn Research Center. The rig consists of a serpentine inlet, a rake assembly, inlet guide vanes, a 12-in. } \\
\text { diameter tip-turbine driven fan stage, exit rakes or probes, and an exhaust nozzle with a translating centerbody. The analyses were done to } \\
\text { develop computational capabilities for modeling inlet/fan interaction and to help interpret experimental data. Three-dimensional Reynolds } \\
\text { averaged Navier-Stokes (RANS) calculations of the fan stage were used to predict the operating line of the stage, the effects of leakage from } \\
\text { the turbine stream, and the effects of inlet guide vane (IGV) setting angle. Coupled axisymmetric calculations of a bellmouth, fan, and } \\
\text { nozzle were used to develop techniques for coupling codes together and to investigate possible effects of the nozzle on the fan. RANS } \\
\text { calculations of the serpentine inlet were coupled to Euler calculations of the fan to investigate the complete inlet/fan system. Computed wall } \\
\text { static pressures along the inlet centerline agreed reasonably well with experimental data but computed total pressures at the aerodynamic } \\
\text { interface plane (AIP) showed significant differences from the data. Inlet distortion was shown to reduce the fan corrected flow and pressure } \\
\text { ratio, and was not completely eliminated by passage through the fan. }\end{array}$} \\
\hline \multicolumn{6}{|c|}{$\begin{array}{l}\text { 15. SUBJECT TERMS } \\
\text { Computational fluid dynamics; CFD; Inlet; Fan; Nozzle }\end{array}$} \\
\hline \multicolumn{3}{|c|}{ 16. SECURITY CLASSIFICATION OF: } & $\begin{array}{l}\text { 17. LIMITATION OF } \\
\text { ABSTRACT }\end{array}$ & $\begin{array}{l}\text { 18. NUMBER } \\
\text { OF }\end{array}$ & $\begin{array}{l}\text { 19a. NAME OF RESPONSIBLE PERSON } \\
\text { STI Help Desk (email:help@sti.nasa.gov) }\end{array}$ \\
\hline $\begin{array}{l}\text { a. REPORT } \\
\text { U }\end{array}$ & $\begin{array}{l}\text { b. ABSTRACT } \\
\mathrm{U}\end{array}$ & $\begin{array}{l}\text { c. THIS } \\
\text { PAGE } \\
\text { U }\end{array}$ & UU & $\begin{array}{l}\text { PAGES } \\
19\end{array}$ & $\begin{array}{l}\text { 19b. TELEPHONE NUMBER (include area code) } \\
\text { 443-757-5802 }\end{array}$ \\
\hline
\end{tabular}



